\title{
Effects of Land Cover/Use Change and Altitude on Soil NPK Nutrients in Selected areas in the North West Region of Cameroon
}

\author{
Brenda T. Mbibueh ${ }^{1}$, Reeves M. Fokeng ${ }^{2,}{ }^{*}$, Suiven J.P. Tume ${ }^{2}$
}

1. Department of Development Studies, Pan African Institute for Development-West Africa (PAIDWA), Buea, Cameroon; E-Mail: mbibuehbren@gmail.com

2. Department of Geography and Planning, The University of Bamenda, Cameroon; E-Mails: rfokeng@yahoo.com; wantume@gmail.com

* Correspondence: Reeves M. Fokeng; E-Mail: rfokeng@yahoo.com

Academic Editor: Zed Rengel

Adv Environ Eng Res

2021, volume 2, issue 4

doi:10.21926/aeer.2104038
Received: September 29, 2021

Accepted: December 20, 2021

Published: December 30, 2021

\begin{abstract}
Land-use change is one of the main indicators of soil quality. Soil physical and chemical properties vary with land use change and altitude as inferred from transect surveys and toposequences. Soil nitrogen, phosphorus, and potassium (NPK) are essential macronutrients for plant growth and soil nutrient balance. Their presence in the soil in appropriate quantities is important for maintaining crop yields and farmers income, particularly in developing countries where resources of soil chemical additives may be limited. This paper assesses the effects of land cover/use change and altitude on soil NPK nutrients in plots of $30 \mathrm{~m}^{2}$ in the North West Region of Cameroon for maintaining soil NPK levels and boosting crop yields. A total of 60 soil samples were collected at the $0-20 \mathrm{~cm}$ depth from the plots with various land cover/use types (eucalyptus plantation, farmland, grazing land, and natural forest). Soil samples were analyzed for nitrogen $(N)$, phosphorus $(P)$, and potassium $(K)$ contents based on standard procedures. The concentrations of soil NPK nutrients were below the critical values for different land use types and the studied sites. The decline in soil NPK nutrient contents is partly linked to land use change, long-term nutrient mining through crop harvest, and rainfallinduced leaching of $\mathrm{N}$ and $\mathrm{K}$ nutrients. To increase food crop yields and sustain the livelihood of farmers, appropriate nature-based solutions of manure application, mulching, the
\end{abstract}

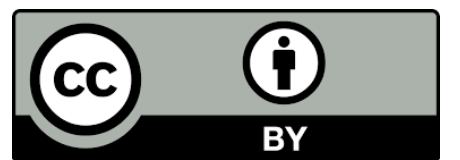


intercropping of legumes, and sustainable use of appropriate chemical NPK fertilizers will help restore the soils and increase crop yields.

\section{Keywords}

Crop yield gaps; food security; land use change; NPK; soil fertility decline; topographic variations

\section{Introduction}

Globally, the land becomes an integral part of human survival and development [1], as soils have played pivotal roles in the Earth's ecosystem for decades [2]. Population growth and demand pressures alongside human activities have progressively threatened this renewable resource [3], upon which humans rely to meet their spiritual, social, material, environmental, and cultural needs [1]. Land use and soil management practices, climatic conditions, the degree of soil development, cultivation intensity, and the parent materials from which the soil is formed, among others, have caused environmental degradation, inhibiting sustainable agricultural production to the extent that urgent remedial actions are required to minimize the decline in soil quality and subsequently in the fertility which is a major development challenge [4]. Characterizing spatial variability of soil nutrients in relation to site properties, including climate, land use, landscape position, etc., is important for understanding how ecosystems work and also assessing the effects of future land use changes on soil nutrients [5]. Agricultural land use and management practices may affect soil properties, which play critical roles in sustaining crop production [6]. Altitude is a determining factor of ecosystem services and processes in mountains [7]. Knowledge of soil resources and their agricultural potentials as important factors for sustainable agricultural land use planning and management are required $[8,9]$.

Soil fertility in Africa is under pressure, as an increasing number of farmers attempt to make a living based on what the land can offer to grow plants [10]. Soil fertility challenges in Sub-Saharan Africa can be very serious, as large areas in Africa are characterized by strongly acid soils with aluminum toxicity [2] which are limiting to crop growth. Deteriorating soil fertility, associated with nutrient depletion and unsustainable cropping practices, has been widely reported across Tropical Africa. Improving food security in Africa would require a good understanding of the yields of farming systems as well as reducing yield gaps [11]. In Cameroon, soil fertility status is the backbone on which all input-based high agricultural production systems can be built [12]. Soil quality highly estimates crop yields since plants, like other living organisms, require nutrients for their growth, development, and reproduction [13]. However, soil fertility has declined as a result of poor and unimproved farming practices, such as excessive use of agrochemicals, intensive shifting cultivation, slash-and-burn cultivation practices, induced leaching, and soil erosion. Therefore, crops grown with an inadequate supply of nutrients cause soil fertility deterioration and the emergence of multinutrient deficiencies under intensive farming systems in this area [14]. Continuous cropping under such systems has led to nutrient mining, further soil fertility decline, and keeping farmers in a poverty trap via crop yield decline. 
In the North West Region of Cameroon, increased intensive cropping without sufficient organic and mineral inputs is commonplace. This deteriorates the functional or productive capacity of the soil as a result of negative changes in its physical, chemical, biological, and hydrological properties. Thus, it is necessary to adopt soil fertility management practices to remove constraints associated with soil fertility through intensification of campaigns for green manures, organic manures, and composts, and judicious use of chemical fertilizers [14]. Nevertheless, soil fertility management practices in this region cannot be promoted without an appropriate and rapid assessment of soil nutrient status so that decision-makers and farmers can be careful about the soil fertility problems and thus accordingly make rational decisions to improve crop yields and better manage soil nutrients. According to [15], soils are exposed to six types of land uses in the North West Region of Cameroon, and the constant loss and conversion of forest to farmland critically influence human vulnerability, landscape design, biodiversity, and atmospheric environment, as well as the sustainability of resources. [16] reported that altitudinal gradients directly affected soil characteristics which in turn had an impact on the soil-water-plant relationships. Therefore, it is vital to assess the spatial variability of soil properties to arrive at the best management decisions, such as the selection of appropriate fertilizer doses, as well as the methods and frequency of its application [17]. Few studies [15, 18] have evaluated the variability of soil essential nutrients with land use change and altitude in the Western Highlands of Cameroon. The knowledge about the nutrient requirements of crops and soil nutrient status is vital for improving yields. This study looked into the effects of land cover/use change and altitude on soil NPK nutrients in selected sites of the North West Region of Cameroon. Soil NPK are essential macronutrients required for plant growth, and therefore a clear understanding of their appropriate quantities present is important for increasing yields in both subsistence and commercial farming systems alongside the farmers income. NPK are the three most indispensable and usually deficient elements for crop production in the tropics [19]. These soil properties vary widely with soil types, which in turn control water and nutrient uptake by plants [16]. We thus assessed the variability of soil NPK macronutrients across four land use types, namely eucalyptus plantation, farmland, grazing land, and forest in selected sites in the North West Region of Cameroon.

\subsection{Study Area}

The North West Region of Cameroon is surrounded by the Republic of Nigeria in the north and west, by the West and South West Regions in the south, and by the Adamawa Region in the east, covering a surface area of about $17,400 \mathrm{~km}^{2}$ and extending between latitudes $5.45^{\circ} \mathrm{N}-9.9^{\circ} \mathrm{N}$ and longitudes $9.13^{\circ} \mathrm{E}-11.13^{\circ} \mathrm{E}[20]$. The study areas are located in three altitudinal zones (Table 1, Figure 1).

Table 1 Location and topographic factors of the study sites in the North West Region of Cameroon.

\begin{tabular}{lllll}
\hline Study sites & Latitude & Longitude & Altitude $\mathrm{m}$ (asl) & Elevation class \\
\hline Baba II (Santa) & $05^{\circ} 51^{\prime} \mathrm{N}$ & $010^{\circ} 12^{\prime} \mathrm{E}$ & $>1450$ & High \\
Bafut & $05^{\circ} 58^{\prime} \mathrm{N}$ & $010^{\circ} 09^{\prime} \mathrm{E}$ & $850-1450$ & Mid \\
Babungo & $06^{\circ} 03^{\prime} \mathrm{N}$ & $010^{\circ} 28^{\prime} \mathrm{E}$ & $<850$ & Low \\
\hline
\end{tabular}




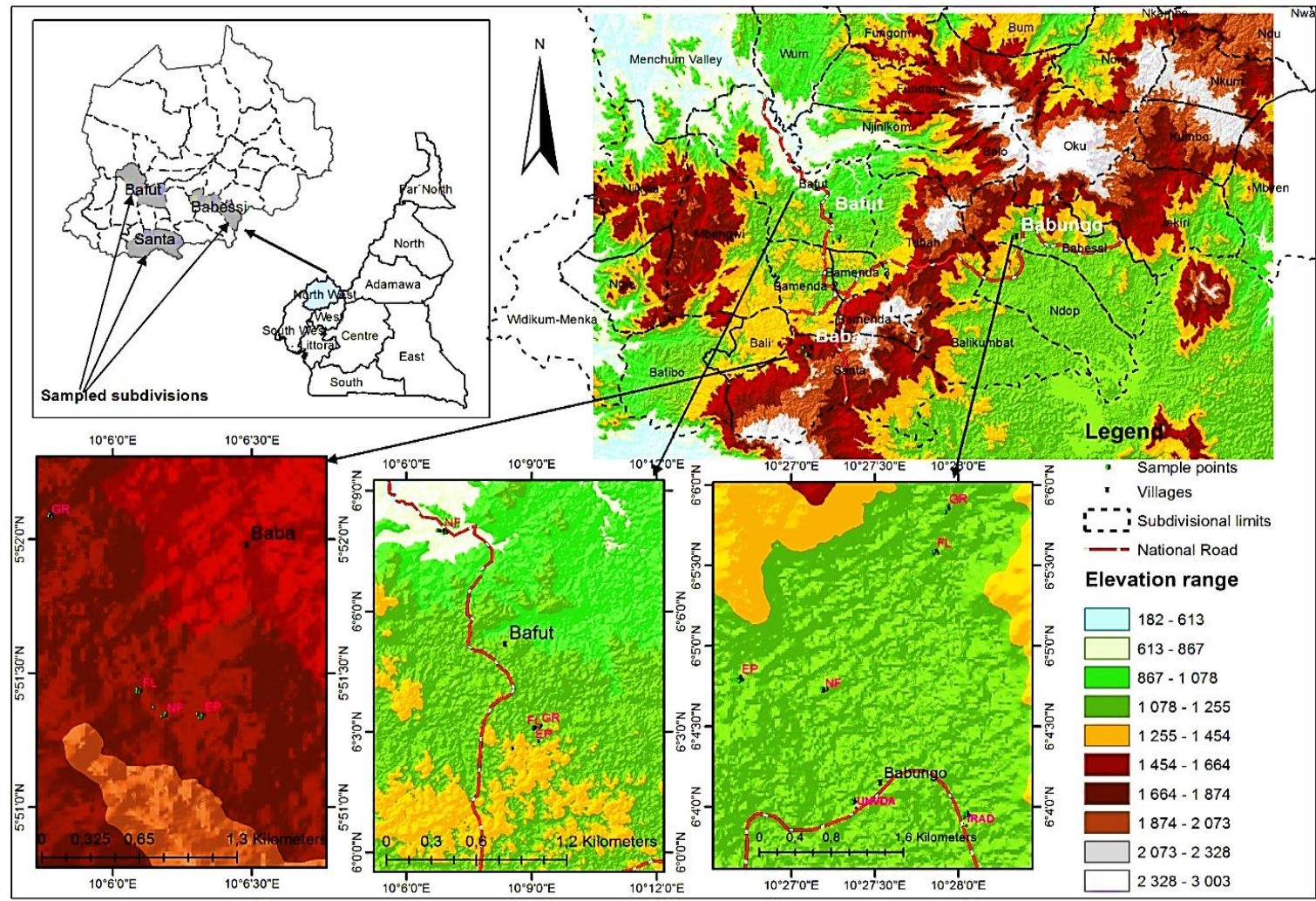

Figure 1 The location of selected sites and soil sampling points. Note: GR (Grassland or grazing land), NF (Natural Forest), EP (Eucalyptus plantation), FL (Farmland).

The three sampled communities represented specific altitudes in the North West Region, including the low altitude ( $<850 \mathrm{~m}$ a.s.I.), the mid-altitude ( $850-1450 \mathrm{~m}$ a.s.I.), and the high altitude (> $1450 \mathrm{~m}$ a.s.l.) (Figure 1 ).

In Baba II (high altitude), there are young soils with some color changes that have rocks at very shallow depths and, thus, are Inceptisols [15]. These soils are highly weathered, red and yellowishred, and with high content of iron and aluminum oxide. The clayey soil has a sandy loam texture and is acidic and generally deep without much horizon differentiation [15]. In this area, the soil is used for the cultivation of crops such as maize (Zea mays ssp.), beans (legumes), carrot (Daucus carota subsp. Sativus), green beans (phaseolus vulgaris), huckleberry (Solanum sp.), and a wide variety of garden crops.

In Bafut (mid-altitude), the distribution of soils is chiefly conditioned by topography and climate. The soil types range from Endisols, those that lack pedogenic horizons and occur on slopes, to Oxisols, which have deep dark red color, are clayey with sandy loam texture, well-structured, slightly acidic, and rich in organic matter, and contain little or no weathered minerals, with a fair to good fertility status [21]. In Babungo (low altitude), soils are alluvial and primarily formed through erosion due to the detachment, transport, and deposition of materials from surrounding hills. The high lava plateaux are covered by humid volcanic soils overlain by the basement complex.

The study sites have different climatic characteristics. In Bafut, the mean annual precipitation is $2657.2 \mathrm{~mm}$, while the mean annual temperature is $22.3^{\circ} \mathrm{C}$, with a long rainy season from March to November and a dry season from December to February [22]. The ecology in this area varies from grasses mixed with deciduous shrubs and stunted trees to swampy valleys dominated by raffia bushes and palm trees [23], which are highly modified by human activities. Bafut is located within 
the Bamenda Mountains along the Cameroon Volcanic Line, particularly along with the WumTungoh sector, and comprises three main geological formations, including volcanic rocks, metamorphic rocks, and alluvial deposits [24]. The metamorphic rocks, mainly gneiss and schist, outcrop principally in the north, especially on slopes with high plateaux, and constitute the basement complex [9]. The relief is a rolling topography of hills and valleys extending to the flood plains of the River Mezam. Thus, red ferrallitic soils occur in the southern high plateau [9]. In the north, the majority of the hill slopes are covered by brunified soils, while alluvial soils are abundant in the Mezam River Valley [9]. Hydromorphic soils are common in swampy valleys [25-27]. Soils from recent lava flows, carrying andosol and laterite, occur in Babungo [28]. Guedjeo et al. [29] reported that Babungo is covered by plutonic rocks (granite and gneiss) and volcanic rocks (basalt, trachyte, and ignimbrite), while flooded plains are covered by alluvium. Santa (Baba) is characterized by three soil types, including the penevoluted ferralitic soils in low-lying parts of Baligham, Santa, and Ndzong, modified orthic soils in highland areas of Akum, Baba, Mbu, and Awing, and the aliatic and penevolated ferralitic red soils in the intermediate relief areas of Mbei and Pinyin [30]. The topography generally includes mountains extending to Mount Bamboutos in the southwest. Santa Highlands on the North West of the Bamboutos Range reaches its peak in Mount Lefo in Awing $(2209 \mathrm{~m})$, presenting an area of irregular relief configuration of highlands and valleys typical of a volcanic terrain [30]. The hydrogeological setting provides a configuration of river valleys that promotes market gardening.

\section{Materials and Methods}

\subsection{Soil Sampling, Processing, and Chemical Analysis}

This study was carried out in three phases, including fieldwork, laboratory, and data analysis (Figure 2).

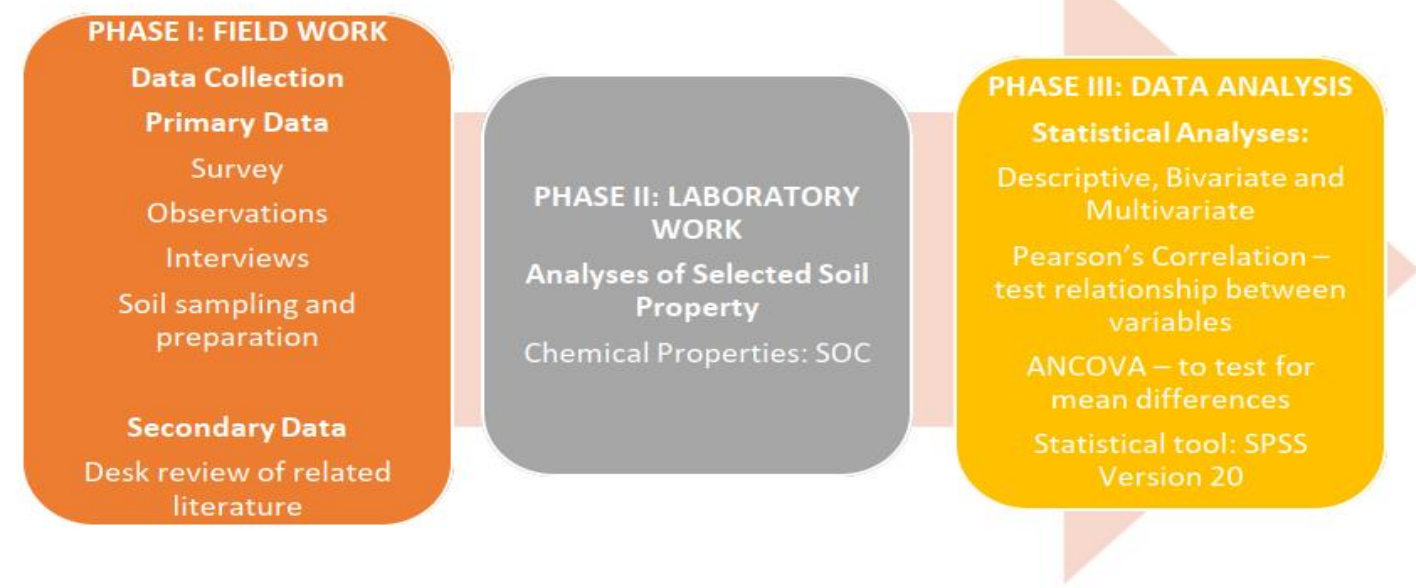

Figure 2 Schematic representation of materials and methods used in the study.

Materials used during the collection included zip-lock plastic bags, tape, metal, trowel, scale, and cups. Both the quantitative and qualitative models were employed to compare the differences in soil quality parameters under four different land use systems using the selected soil quality indicators (NPK) at three topographic locations for proxy assessment of land degradation. In the 
selected study sites, 60 composite soil samples were collected at $0-20 \mathrm{~cm}$ depth from plots of $30 \mathrm{~m}^{2}$ in Baba II, Bafut, and Babungo. These sites were chosen because they are agricultural lands with small-scale agriculture and varied land use practices, including limited control of plant diseases/pests, the use of basic tools and low fertilizer inputs, and low yields. Approximately $1 \mathrm{~kg}$ of the composite soil samples collected using the " $Z$ " design, as described by Carter and Gregorich [31], was transferred to the Laboratory of Soil Analysis and Chemistry of the Environment (LABASCE), Dschang School of Agronomy and Agricultural Sciences. In the laboratory, soil samples were placed on plastic trays, air-dried at room temperature, crushed with a mortar, and passed through a 2-mm sieve before laboratory analysis. The Kjeldahl method was used to determine soil total nitrogen (TN), as described by Bashour and Sayegh [32]. For the extraction of available phosphorus from the soil solutions of $0.1 \mathrm{~N} \mathrm{HCl}$ and $0.03 \mathrm{~N} \mathrm{NH}_{4} \mathrm{~F}$, the molybdenum blue method was used to determine phosphorus colorimetrically with ammonium molybdate solution, while potassium was determined on the Sherwood 410 Flame Photometer after preparing the standard solutions. To ensure future soil nutrient monitoring, we used the Garmin GPSmap 65s to collect the geographic coordinates (XYZ) of each sample point from the selected sites.

\subsection{Data Analysis}

The data were subjected to statistical analysis using Microsoft Excel 2007 and SPSS statistical package 20, while maps showing the areas where soil samples were collected were drawn using QGIS 3.14.1-1. Descriptive statistics, including bivariate and multivariate analyses (mean, frequency, percentage, standard error mean, and standard deviation), were used to analyze soil nutrients. The Pearson product-moment correlation was used to test the linear relationships between soil quality indicators. Analysis of covariance (ANCOVA) was employed to test the significant differences between the means of values obtained under different land use types and elevations.

\section{Results and Discussion}

\subsection{Variations of Soil NPK Nutrients under Land Use Change and Altitude in Selected Sites}

\subsubsection{Variations of Total Nitrogen (TN) with Land Use Change and Altitude}

Total nitrogen exhibited no statistically significant difference with elevation $(p>0.01)$ but was significantly different between various land use types $(p<0.01)$ and also for the between-subjects interaction effect $(p<0.01)$ (Table 2$)$.

Table 2 Correlation matrix ( $r$ values) for the selected chemical soil properties in the study areas.

\begin{tabular}{llll}
\hline Soil trio & $\mathbf{N}(\%)$ & $\mathbf{P}(\mathbf{p p m})$ & $\mathbf{K}^{+}(\mathbf{c m o l}(+) / \mathbf{k g})$ \\
\hline TN $(\%)$ & - & & \\
$\mathbf{P}(\mathbf{p p m})$ & 0.185 & - & - \\
$\mathbf{K}^{+}(\mathbf{c m o l}(+) / \mathbf{k g})$ & 0.233 & $0.276^{*}$ & - \\
\hline * Correlation is significant at the 0.01 level (2-tailed), * Correlation is significant at the 0.05 level \\
(2-tailed).
\end{tabular}


With regard to the mean values of soil NPK, we observed variations with different land use types (Table 3).

Table 3 Means of the estimated soil NPK nutrients at $0-20 \mathrm{~cm}$ soil depth.

\begin{tabular}{lllllll}
\hline Soil nutrients & $\begin{array}{l}\text { Land use types } \\
\text { Eucalyptus }\end{array}$ & Farmland & Grazing land & Natural forest & Total & $\begin{array}{l}\text { P- } \\
\text { value }\end{array}$ \\
& Mean/SD & Mean/SD & Mean/SD & Mean/SD & Mean/SD & \\
\hline $\mathrm{TN}(\%)$ & $0.248 \pm 0.110$ & $0.260 \pm 0.109$ & $0.243 \pm 0.074$ & $0.298 \pm 0.078$ & $0.262 \pm 0.096$ & 0.393 \\
$\mathrm{P}(\mathrm{ppm})$ & $15.186 \pm 14.013$ & $21.001 \pm 8.099$ & $21.432 \pm 1.232$ & $13.851 \pm 6.952$ & $18.315 \pm 10.452$ & 0.660 \\
$\mathrm{~K}^{+}(\mathrm{cmol}(+) / \mathrm{kg})$ & $0.615 \pm 0.199$ & $1.074 \pm 1.370$ & $0.503 \pm 0.389$ & $1.099 \pm 1.028$ & $0.586 \pm 0.988$ & 0.177 \\
\hline
\end{tabular}

SD is the standard deviation, * represents the statistical significance at $p<0.05$

At mid-altitude, soils had the highest fractions of TN under natural forest land cover $(0.21 \%)$, followed by eucalyptus plantation $(0.18 \%)$, while those under farmland had the lowest TN content (0.10\%). No significant differences were found at this altitude and under LULC systems (Table 4).

Table 4 The variation of soil NPK nutrients at $0-20 \mathrm{~cm}$ depth across different LULC systems and altitudes.

\begin{tabular}{|c|c|c|c|c|c|c|}
\hline \multirow{2}{*}{$\begin{array}{l}\text { Soil } \\
\text { properties }\end{array}$} & \multirow[t]{2}{*}{ Altitude (m) } & \multicolumn{4}{|c|}{ Land-use types } & \multirow[b]{2}{*}{ ANOVA } \\
\hline & & Under eucalyptus & Farmland & Grazing land & Natural forest & \\
\hline \multirow[t]{3}{*}{ TN (\%) } & High (>1500 m) & $0.314 \pm 0.172$ & $0.352 \pm 0.026$ & $0.316 \pm 0.052$ & $0.320 \pm 0.024$ & NS \\
\hline & $\operatorname{Mid}(900-1500 \mathrm{~m})$ & $0.180 \pm 0.028$ & $0.104 \pm 0.011$ & $0.168 \pm 0.049$ & $0.208 \pm 0.044$ & $*$ \\
\hline & Low (<900 m) & $0.250 \pm 0.187$ & $0.281 \pm 0.088$ & $0.244 \pm 0.011$ & $0.366 \pm 0.047$ & NS \\
\hline \multirow{3}{*}{$\begin{array}{l}\text { Phosphorus } \\
\text { (ppm) }\end{array}$} & High (>1500 m) & $29.826 \pm 13.560$ & $24.438 \pm 2.966$ & $23.152 \pm 1.478$ & $17.938 \pm 2.782$ & NS \\
\hline & $\operatorname{Mid}(900-1500 \mathrm{~m})$ & $14.174 \pm 10450$ & $12.062 \pm 0.461$ & $27.998 \pm 15.287$ & $14.622 \pm 0.644$ & $*$ \\
\hline & $\operatorname{Low}(<900 \mathrm{~m})$ & $1.558 \pm 0.126$ & $22.835 \pm 8.573$ & $13.146 \pm 7.890$ & $8.994 \pm 10.483$ & $*$ \\
\hline Ex. $\mathrm{K}^{+}(\mathrm{cmol}(+)$ & High (>1500 m) & $0.736 \pm 0.150$ & $1.038 \pm 0.075$ & $0.914 \pm 0.445$ & $2.260 \pm 1.010$ & NS \\
\hline \multirow[t]{2}{*}{ /kg) } & $\operatorname{Mid}(900-1500 \mathrm{~m})$ & $0.560 \pm 0.236$ & $0.262 \pm 0.059$ & $0.338 \pm 0.095$ & $0.304 \pm 0.114$ & NS \\
\hline & Low $(<900 \mathrm{~m})$ & $0.548 \pm 0.180$ & $1.357 \pm 1.700$ & $0.258 \pm 0.058$ & $0.732 \pm 0.152$ & NS \\
\hline
\end{tabular}

Means within the same row followed by the same letters are not significantly different at 0.01 level. * Significant at $\mathrm{P}<0.01$

Ns non-significant; $T N$ total nitrogen; (Ex.) Exchangeable $K^{+}$Potassium

At high altitudes, the mean percentage of TN was high in soils under farmland (0.35\%) but low in soils under eucalyptus plantation (0.31\%). Altitude exhibited no statistical significance $(P>0.001)$ under LULC systems (Table 5). As expected, the mean values of TN were high in soils of forest land at all topographic classes because these soils had higher organic matter (OM) contents than soils under other land use types; this is in agreement with the findings of [33]. 
Table 5 The summary of ANOVA for Total Nitrogen, Phosphorous, and Potassium across different land cover/use types and altitudes.

\begin{tabular}{llllllll}
\hline Sources of variations & \multicolumn{2}{l}{ TN (\%) } & \multicolumn{3}{c}{ Phosphorous (ppm) } & \multicolumn{2}{c}{ Ex. $\mathrm{K}^{+}(\mathrm{cmol}(+) / \mathrm{kg})$} \\
& $\mathrm{df}$ & $\mathrm{MS}$ & $\mathrm{P}$ & $\mathrm{MS}$ & $\mathrm{P}$ & $\mathrm{MS}$ & $\mathrm{P}$ \\
\hline Land use (LU) & 3 & 0.011 & 0.093 & 203.070 & 0.024 & 1.099 & 0.257 \\
Elevation (E) & 2 & 0.141 & 0.000 & 812.550 & 0.000 & 3.839 & 0.011 \\
LU * E & 6 & 0.008 & 0.123 & 357.811 & 0.000 & 1.473 & 0.104 \\
Error & 58 & 0.005 & - & 59.888 & - & 0.793 & - \\
\hline
\end{tabular}

$\mathrm{MS}$ is the mean square; $\mathrm{P}$ is the $\mathrm{p}$-value; $\mathrm{df}$ is the degree of freedom

The relatively high $\mathrm{TN}$ content in farmland is linked to a high application rate of nitrogen fertilizer, while grazing land exhibited low TN content because the soils were sandy, thereby having limited nitrogen retention capacity, which is in line with the results reported by [34]. In accordance with the results of the study conducted by [35], the low TN content in farmland is due to the continuous decline in the soil OM content; thus, indicating the deficiencies of $\mathrm{N}, \mathrm{S}$, and $\mathrm{P}$ in low-input farming systems. In conformity with the results obtained by [36], TN content of the soils were high in natural forest but low in farmland at mid-altitude. Furthermore, the burning of grasslands resulted in the production of ashes rich in $\mathrm{K}, \mathrm{N}$, and other key nutrients in grazing lands. This could explain the presence of higher amounts of nitrogen in soils under grazing land use compared to those under farmland and eucalyptus plantation. Moreover, [15] confirmed that the high OM content in grazing lands from cow dung are strongly associated with high nitrogen content. At low altitudes, natural forestland had a very high TN content $(0.37 \%)$, followed by farmland $(0.28 \%)$, while grazing land showed the lowest TN value (0.24\%), close to that found under eucalyptus plantation (0.25) (Figure 3).

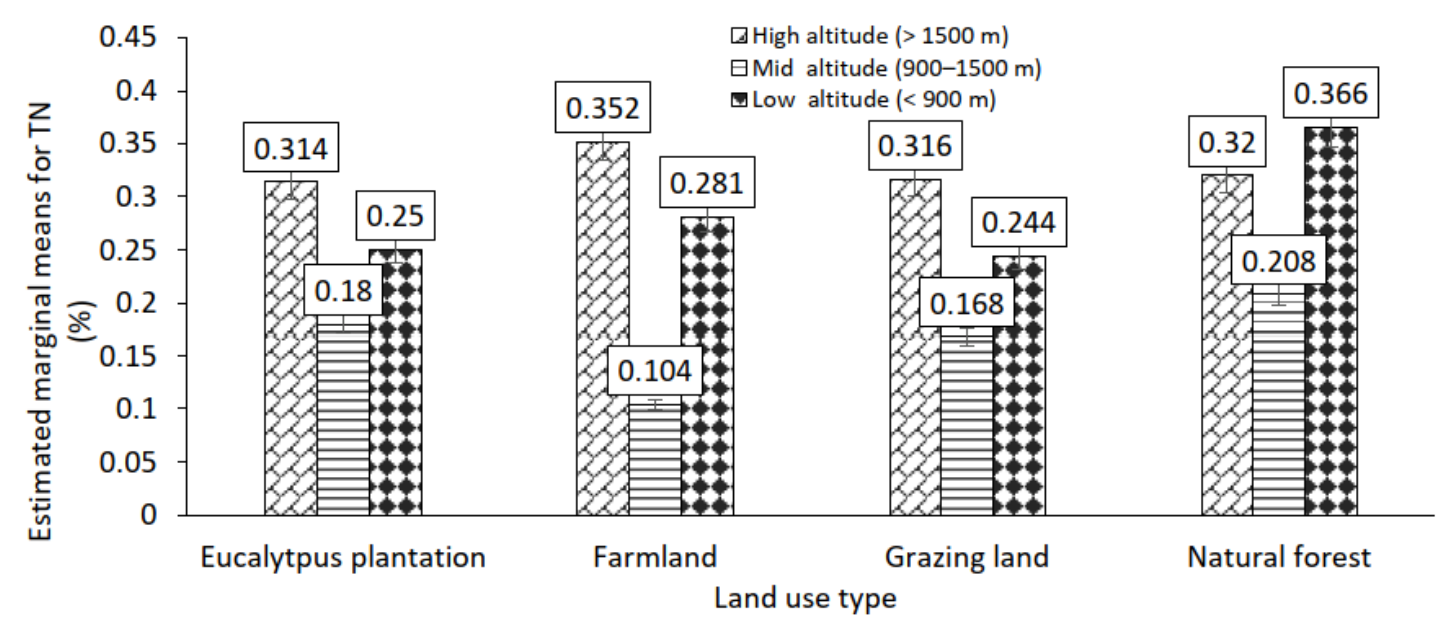

Figure 3 The estimated marginal means of Total Nitrogen (\%) across different land cover/use types and altitudes.

The soil surface $(0-20 \mathrm{~cm})$ showed no significant difference $(P>0.01)$ among the soils under all LULC systems. Based on the value suggested by [37], the TN contents of soils under eucalyptus plantation, farmland, grazing land, and natural forestland were high at all elevations. 


\subsubsection{Phosphorous (P)}

Soil available phosphorus showed statistically significant differences at different altitudes $(\mathrm{P}<$ $0.001)$ and also significant between-subjects interaction effect $(P<0.001)$ but no statistically significant difference between land use types $(P>0.001$ ) (Table 2$)$. The $p$-values for soils under eucalyptus plantation ranged from $1.56 \mathrm{ppm}$ at low altitude to $29.83 \mathrm{ppm}$ at high altitude. P contents decreased with decreasing elevation under eucalyptus plantation, farmland, and natural forestland, while they fluctuated for grazing land.

The results revealed variations at high altitudes where soils under eucalyptus plantation had the highest P content (29.83 ppm), followed by farmland (24.44 ppm), whereas grazing land and natural forestland had relatively lower $P$ (23.15 ppm and $17.94 \mathrm{ppm}$, respectively) (Figure 4). There was no statistically significant difference between $P$ content in all land use types $(P>0.01)$ at this altitude. The significant reduction in $P$ contents in soils under natural forestland could be attributed to the transport of particulate $P$ by erosion and runoff into streams and rivers, as well as the low-P status of the parent material [19].

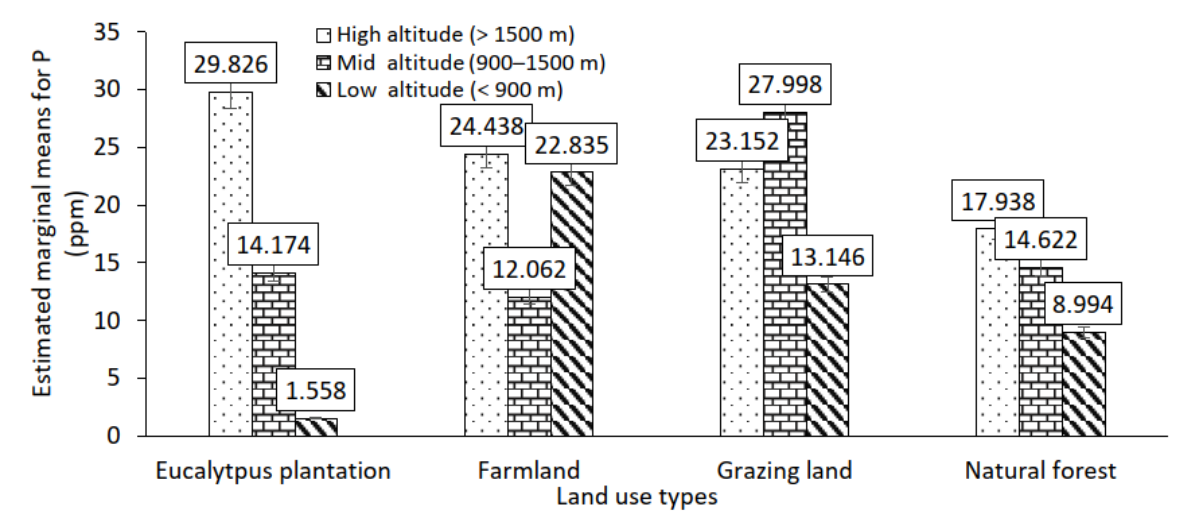

Figure 4 The estimated marginal means of phosphorus (ppm) across different land cover/use types and altitudes.

The results indicated that at the mid-altitude, soils under grazing land had the highest $\mathrm{P}$ content (28.00 ppm), followed by natural forestland (14.62 ppm), while eucalyptus plantation and farmland had relatively lower $\mathrm{P}$ content (14.17 ppm and $12.06 \mathrm{ppm}$, respectively). There was also no statistically significant difference between $P$ content for all land cover/use types $(P>0.01)$ at this altitude, which indicates the inadequacy of available $P$ in the soils under farmland, thereby limiting plant growth in both cultivated and uncultivated lands [38]. The frequent burning of grazing fields by cattle herdsmen along with cow dung may account for the high $\mathrm{P}$ content in grazing lands. These findings correspond to those of the study carried out by Tellen and Yerima [15], who reported that burning resulted in the formation of ash deposits, which enhanced $P$ concentration with an increased application rate of organic manure and $P$ fertilizers.

At the low altitude, the highest $P$ content was obtained under farmland (22.84 ppm), followed by grazing land (13.15 ppm). Soils under natural forestland and eucalyptus plantation had relatively lower $\mathrm{P}$ content (8.99 ppm and $1.56 \mathrm{ppm}$, respectively) (Figure 4). No statistically significant difference was observed between land use types $(P>0.01)$ at this altitude. The high $P$ content in farmland may be due to the continuous application of $P$ fertilizers in the soil by farmers. These 
findings correlate with those obtained by [39]; [40, 41], who stated that $P$ availability characterized in soils under farmland resulted from the high concentration of available $P$ with the application of $P$ fertilizers.

Furthermore, Voundi et al. [42] asserted that the burning of household and floral wastes and crop residues which produce wood ashes in soils under farmland, is a good source of $\mathrm{P}, \mathrm{K}^{+}, \mathrm{Ca}^{2+}$, and $\mathrm{Mg}^{2+}$; thus, explaining the high P content in soils under farming systems where 'Ankara' (burning of grass within the soil) was practiced. Based on the rates obtained by Landon [43], available soil P in the study area ranged from low to high ( $1.56 \mathrm{ppm}$ at high altitude to $29.86 \mathrm{ppm}$ at low altitude) for eucalyptus plantation. This is in line with the results reported by many authors, including [44, 45], who stated that the availability of $P$ in most soils of the North West Region of Cameroon was very low for all land use types due to the impacts of erosion, P-fixation, crop harvest, and inherently low$P$ status of the parent material.

\subsubsection{Exchangeable Potassium $\left(\mathrm{K}^{+}\right)$}

Exchangeable potassium $\left(\mathrm{K}^{+}\right)$varied but showed no statistically significant differences between different land use types $(P>0.001)$ and elevations $(P>0.001)$ and also for between-subjects interaction effect $(P>0.001)$ (Table 2$)$. This variation occurred between $0.26 \mathrm{cmol}(+) / \mathrm{kg}$ to 2.20 $\mathrm{cmol}(+) / \mathrm{kg}$. The highest exchangeable $\mathrm{K}^{+}(2.20 \mathrm{cmol}(+) / \mathrm{kg})$ was recorded under natural forestland use type at the high altitude, whereas the lowest $(0.26 \mathrm{cmol}(+) / \mathrm{kg})$ was obtained under farmland $(2.20 \mathrm{cmol}(+) / \mathrm{kg})$ at the mid-altitude (Figure 5). The exchangeable $\mathrm{K}^{+}$of soils in the study area was within the range of very low to very high, according to the rates achieved by FAO [46]. At the high altitude, natural forestland and farmland had higher $\mathrm{K}^{+}$values $(2.20 \mathrm{cmol}(+) / \mathrm{kg}$ and $1.04 \mathrm{cmol}(+) / \mathrm{kg}$, respectively) than eucalyptus plantation $(0.91 \mathrm{cmol}(+) / \mathrm{kg})$ and grazing land $(0.74 \mathrm{cmol}(+) / \mathrm{kg})$.

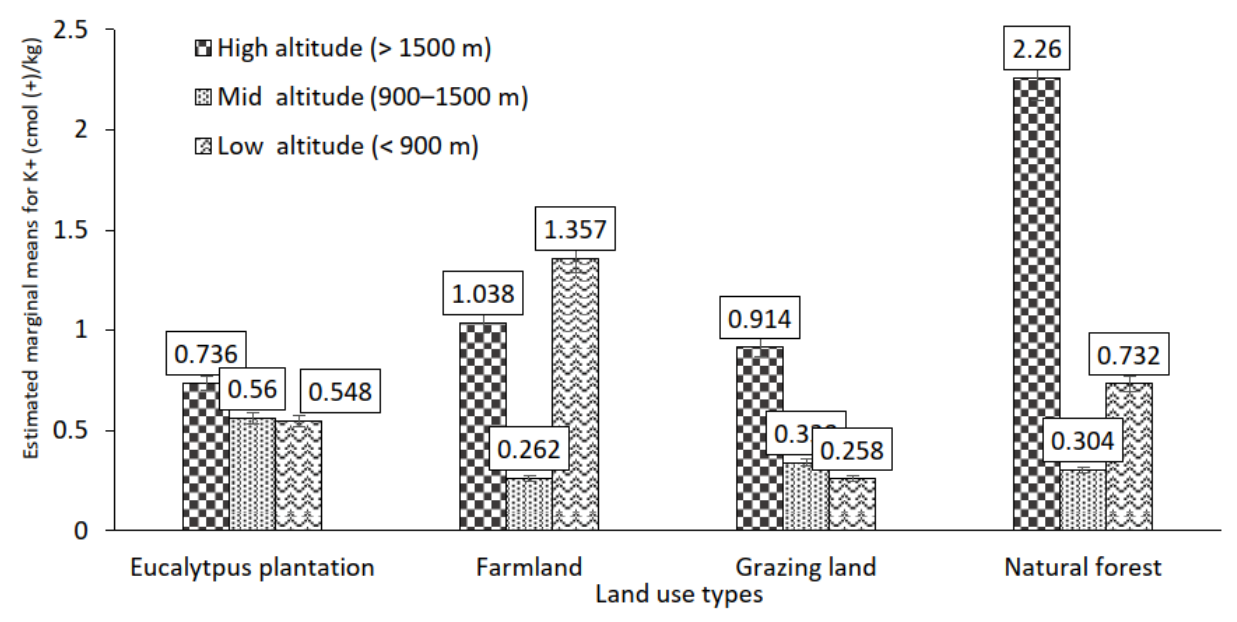

Figure 5 The estimated marginal means of potassium $(\mathrm{cmol}(+) / \mathrm{kg})$ across different land cover/use types and altitudes.

There was no significant difference $(P>0.001)$ between different land use types. This finding agrees with those obtained by [47], who stated that the relative pumping of $\mathrm{K}^{+}$from the subsoil to topsoil by vegetation might account for the relatively high exchangeable $\mathrm{K}^{+}$in soils in the natural forest system. 
At the mid-altitude, eucalyptus plantation and grazing land had higher exchangeable $\mathrm{K}^{+}$values $(0.56 \mathrm{cmol}(+) / \mathrm{kg}$ and $0.34 \mathrm{cmol}(+) / \mathrm{kg}$, respectively) than natural forestland $(0.30 \mathrm{cmol}(+) / \mathrm{kg})$ and farmland $(0.26 \mathrm{cmol}(+) / \mathrm{kg})$ (Figure 5$)$. There was no significant difference $(P>0.001)$ in exchangeable $\mathrm{K}^{+}$between different land use types (Table 3 ). The high clay content in soils under eucalyptus plantation explains the greater availability of $\mathrm{K}^{+}$in soils, which is in line with the results published by [21], who stated that generally, soils with high activity of clay experience less severe $\mathrm{K}^{+}$losses, and $\mathrm{K}^{+}$from fertilizer application move into the deeper soil profile. $[48,49]$ also reported low exchangeable $\mathrm{K}^{+}$in acidic soils under intensive cultivation.

At the low altitude, farmland and natural forestland had higher $\mathrm{K}^{+}$values $(1.36 \mathrm{cmol}(+) / \mathrm{kg}$ and $0.73 \mathrm{cmol}(+) / \mathrm{kg}$, respectively) than eucalyptus plantation $(0.55 \mathrm{cmol}(+) / \mathrm{kg})$, and grazing land $(0.26$ $\mathrm{cmol}(+) / \mathrm{kg})$. There was no significant difference $(P>0.001)$ in $\mathrm{K}^{+}$between different land use types. As a result of common burning practices of household wastes and farm residues, wood ash increased $\mathrm{K}^{+}$contents in farmland; this corroborates with the results reported earlier [47].

Generally, the variations of $\mathrm{K}^{+}$were consistent; $\mathrm{K}^{+}$value decreased with decreasing altitude, except for farmland where irregularities, resulting from intensive cultivation, weathering, the use of acid-forming inorganic fertilizers such as nitric and sulfuric acid, and also from decaying organic matter and oxidation of ammonium and sulfur fertilizers, were observed. Strongly acidic soils are usually formed as a result of the activity of these strong organic and inorganic acids. This finding agrees with the study of [50], which found that these factors affect $\mathrm{K}^{+}$distribution and enhance depletion in the soil system. Another study [51], also revealed that soil management practices, particle size distribution, degree of weathering, mineralogy, climatic conditions, soil development, cultivation intensity, and the parent material from which the soil is formed, determine the variation of $\mathrm{K}^{+}$distribution.

\subsection{Variability of Soil NPK Nutrients and Implications on Crop Nutrient Requirements}

This study assessed the variation in properties of LULC and the mean percentage of these properties at $0-20 \mathrm{~cm}$ depth. The findings showed no significant difference $(P>0.01)$ between the soils under some LULC systems for NPK. This partly implies the deficiencies of soil NPK macronutrients which are also limiting crop growth. Table 6 shows the critical values of soil NPK macronutrients required for crop growth.

Table 6 Critical values of soil NPK macronutrients for determining crop nutrient requirements.

\begin{tabular}{llllll}
\hline & \multicolumn{5}{c}{ Critical values } \\
\hline Properties & Very low & Low & Medium & High & Very high \\
$\mathbf{K}(\mathbf{c m o l} / \mathbf{k g})$ & $<0.1$ & $0.1-0.3$ & $0.3-0.6$ & $0.6-1.2$ & $>1.2$ \\
Bray 2-P $(\mathbf{m g} / \mathbf{k g})$ & $<7$ & $7-16$ & $16-46$ & $>46$ & \\
Total N (\%) & $<0.5$ & $0.5-1.25$ & $1.25-2.25$ & $2.25-3.0$ & $>3.0$ \\
\hline
\end{tabular}

Source: Adapted from the paper published by [52-54]

According to the rates obtained by [52-54], soil NPK macronutrients in the study areas displayed variations based on land use types and altitudes. On the one hand, soil $\mathrm{N}$ content was very low in all land uses and altitudinal classes, implying the dire need for the application of NPK fertilizers in 
this area to boost yields. On the other hand, $\mathrm{P}$ content varied and ranged from very low to medium at different altitudes and in different land uses as a result of erosion and inherent low-P status of the parent material. Finally, the values of $\mathrm{K}$ content showed consistent variations with decreasing elevation, ranging from very high to high with differences in farmlands, mostly due to human activities which caused the increased depletion of soil. This has been confirmed by similar studies conducted in the North West Region $[55,56]$. These deficiencies are highly linked to the acidity of soils in this region as reported by [56]. P deficiency is partly explained by the long-term nutrient mining, inter-annual crop cultivation, increased soil erosion, and soil acidity [55], which are commonplace in the North West Region of Cameroon. The balanced high concentrations of NPK are needed for crop growth and obtaining high yields [55]. The amount of phosphorus absorbed by soils is highly related to those of exchangeable aluminum, total iron, and organic matter, as well as low $\mathrm{pH}[56,57]$. The deficiency of phosphorus $(\mathrm{P})$ is especially the major limiting factor to crop productivity in tropical regions [58]. Nitrogen is highly mobile and therefore easily lost [56], thereby necessitating the continuous fertilizer application for crop growth and development.

\section{Conclusion}

This study revealed considerable soil NPK macronutrients variability in the study area across different altitudinal classes and land use types. The conversion of natural forest and grazing land to farmland and eucalyptus plantation greatly affected nitrogen, phosphorus, and potassium concentrations at different topographic profiles in the North West Region of Cameroon. These land use conversions, mainly caused by deforestation, significantly reduce $(P<0.001)$ the concentrations of soil NPK macronutrients particularly in farmlands, resulting in a series of issues associated with environmental and resource sustainability. Consequently, land use change combined with elevation class affected soil NPK nutrients, as observed in the selected sites. This study, therefore, provides baseline information on the selection of effective soil improvement methods and/or additives to increase the concentrations of soil NPK macronutrients and crop yields. Thus, a proper selection of appropriate NPK chemical fertilizer types and adequate application rates, the effective use of organic manures, land preparation, and cropping practices that increase $\mathrm{pH}$, soil organic matter (OM) and organic carbon (SOC) content, whose presence are linked to that of soil macronutrients (NPK). It is therefore imperative to further investigate the suitability of different types of chemical fertilizers on various agricultural plots for the judicious use of suitable types of soil NPK fertilizers by farmers and their required quantities, as well as appropriate timing. This would help to reduce crop yield gaps and improve farmers income and livelihood in rain-fed cropping systems.

\section{Author Contributions}

Mbibueh designed the research, did data collection and wrote the manuscript with Fokeng. Tume did the statistical data analysis, edited and improved the manuscript.

\section{Competing Interests}

The authors have declared that no competing interests exist. 


\section{References}

1. Nguh BS, Maluh NB. The implications of land use/cover dynamics on resources development in Tubah sub-division, Cameroon. J Archit Eng Technol. 2017; 6: 204.

2. Chianu JN, Chianu JN, Mairura F. Mineral fertilizers in the farming systems of sub-Saharan Africa. A review. Agron Sustain Dev. 2012; 32: 545-566.

3. Certini G, Scalenghe R. Soils: Basic concepts and future challenges. Cambridge: Cambridge University Press; 2006.

4. Ngome AF, Becker M, Mtei MK, Mussgnug F. Maize productivity and nutrient use efficiency in Western Kenya as affected by soil type and crop management. Int J Plant Prod. 2013; 7: 517536.

5. Wang J, Fu B, Qiu Y, Chen L. Soil nutrients in relation to land use and landscape position in the semi-arid small catchment on the loess plateau in China. J Arid Environ. 2001; 48: 537-550.

6. Chen L, Qi X, Zhang X, Li Q, Zhang Y. Effect of agricultural land use changes on soil nutrient use efficiency in an agricultural area, Beijing, China. Chin Geogr Sci. 2011; 21: 392-402.

7. He X, Hou E, Liu Y, Wen D. Altitudinal patterns and controls of plant and soil nutrient concentrations and stoichiometry in subtropical China. Sci Rep. 2016; 6: 24261.

8. Nguemezi C, Tematio P, Yemefack M, Tsozue D, Silatsa TB. Soil quality and soil fertility status in major soil groups at the Tombel area, South-West Cameroon. Heliyon. 2020; 6: e03432.

9. Tamfuh PA, Temgoua E, Wotchoko P, Boukong A, Bitom D. Soil properties and land capability evaluation in a mountainous ecosystem of North-West Cameroon. J Geosci Environ Prot. 2018; 6: 15-33.

10. Smaling EM, Nandwa SM, Janssen BH. Soil fertility in Africa is at stake. In: Replenishing soil fertility in Africa. Madison: American Society of Agronomy and Soil Science Society of America; 1997. pp.47-61.

11. Khechba K, Laamrani A, Dhiba D, Misbah K, Chehbouni A. Monitoring and analyzing yield gap in Africa through soil attribute best management using remote sensing approaches: A review. Remote Sens. 2021; 13: 4602.

12. Tamungang NE, Biosengazeh NF, Alakeh MN, Tameu DY. Quality control of domestic water in Babessi village in North-West Cameroon. Int J Biol Chem Sci. 2016; 10: 1382-1402.

13. Seth A, Sarkar D, Masto RE, Batabyal K, Saha S, Murmu S, et al. Critical limits of Mehlich 3 extractable phosphorous, potassium, sulfur, boron and zinc in soils for nutrition of rice (Oryza sativa L.). J Soil Sci Plant Nutr.2018; 18: 512-523.

14. Ngome AF, Becker M, Mtei KM, Mussgnug F. Fertility management for maize cultivation in some soils of Western Kenya. Soil Tillage Res. 2011; 117: 69-75.

15. Tellen VA, Yerima BP. Effects of land use change on soil physicochemical properties in selected areas in the North West region of Cameroon. Environ Syst Res. 2018; 7: 3.

16. Deb P, Debnath $\mathrm{P}$, Denis AF, Lepcha OT. Variability of soil physicochemical properties at different agroecological zones of Himalayan region: Sikkim, India. Environ Dev Sustain. 2019; 21: 2321-2339.

17. Budak M. Importance of spatial soil variability for land use planning of a farmland in a semi-arid region. Fresenius Environ Bull. 2014; 27: 5053-5065. 
18. Azinwi Tamfuh T, Chotangui AH, Kate VY, Achantap RA, Magha AM, Moundjeu DE, et al. Land characteristics and agricultural suitability status along a toposequence in Santa, Bamenda Highlands, Cameroon. J Atmos Earth Sci. 2020; 4: 022.

19. Brady N, Weil R. The nature and properties of soils. 13th ed. Upper Saddle River: Prentice Hall; 2002.

20. Manu IN, Andu WN, Tarla DN, Agharih WN. Causes of cattle theft in the North West region of Cameroon. Scholarly J Agric Sci. 2014; 4: 181-187.

21. Yerima PK. Protective measures taken for preserving species endangered of extinction due to the climate change in sub-Sahara Africa: Case of the Yongka Western Highlands Research Garden-Park, Nkwen-Bamenda, NW Region, Cameroon. Research and Development in subSaharan Africa, Support Africa International; 2011.

22. Etia PM. Climate and climatic zones of cameroon. In: Les Atlas Jeune Afrique. Paris: Editions J.A; 1980. pp.16-19.

23. Letouzey R. Notice de la carte phytogeographique du Cameroun au1/500000. Toulouse: Institut de la Carte de Végétation; 1985.

24. Kamgang P. Pétrologie et geochimie d'un secteur cle de la ligne du Cameroun, Les monts Bamenda: Implications sur la genese et l'evolution des magmas. Yaoundé: The University of Yaoundé; 2003. pp.373.

25. Gavaud M, Muller JP. Soil map of Cameroon. In: Les Atlas Jeune Afrique. Paris: Editions J.A; 1980. pp.25-27.

26. Ngum NM. Hydrochemical and bacteriological study of spring water sources in Bafut subdivision (North West Region, Cameroon). Bamenda: University of Bamenda; 2013. pp.71.

27. Neh FM. Petrography, hydrochemistry and bacteriological study of springs in Bafut east (North West Region, Cameroon). Bamenda: University of Bamenda; 2016. pp.70.

28. Guedjeo CS, Kagou DA, Ngapgue F, Nkouathio DG, Zangmo TG, Gountié DM, et al. Natural hazards along the Bamenda escarpment and its environs: The case of landslide, rock fall and flood risks (Cameroon volcanic line, North-West Region). Global Adv Res J Geol Min Res. 2013; 2: $15-26$.

29. Wotchoko P, Bardintzeff JM, Itiga Z, Nkouathio DG, Guedjeo CS, Ngnoupeck G, et al. Geohazards (floods and landslides) in the Ndop plain, Cameroon volcanic line. Open Geosci. 2016; 8: 429449.

30. Zephania NF. Montane resources exploitation and the emergence of gender issues in Santa economy of the western Bamboutos highlands, Cameroon. Int J Geo Reg Plan Res. 2014; 1: 112.

31. Carter MR, Gregorich EG. Soil sampling and methods of analysis. 2nd ed. Boca Raton: CRC Press; 2008.

32. Bashour II, Sayegh AH. Methods of analysis for soils of arid and semi-arid regions. Rome: Food and Agriculture Organization of the United Nations; 2007.

33. Mengel K, Kirkby EA. Principles of plant nutrition. Berne: International Potash Institute; 1987.

34. Zhang $P$, Zhang $T$, Chen NL. Vertical distribution patterns of soil organic carbon and total nitrogen and related affecting factors along northern slope of Qilian Mountains. Chin J Appl Ecol. 2009; 20: 518-524.

35. Adugna A, Abegaz A. Effects of land use changes on the dynamics of selected soil properties in northeast Wellega, Ethiopia. Soil. 2016; 2: 63-70. 
36. Abera Y, Belachew T. Land use effects on soil organic carbon and nitrogen in some soils of bale, southeastern Ethiopia. Trop Subtrop Agroecosystems. 2010; 14: 229-235.

37. Tekalign T. Soil, plant, water, fertilizer, animal manure and compost analysis. Working Document No. 13. Addis Ababa: International Livestock Research Center for Africa; 1991.

38. Foth HD, Ellis BG. Soil fertility. 2nd ed. Boca Raton: Lewis CRC Press LLC.; 1997.

39. Whitbread AM, Lefroy RD, Blair GJ. A survey of the impact of cropping on soil physical and chemical properties in north-western New South Wales. Soil Res. 1998; 36: 669-682.

40. Kefale T. Effects of topographic positions and slope aspects on selected soil properties under different land use types in Bollen watershed of Womberma district, Northwestern Ethiopia. Haramaya: Haramaya University; 2013.

41. Tekalign M, Haque I, Kamara CS. Phosphorus status of Ethiopian Vertisols: Management of Vertisols in Sub-Saharan Africa. Proceedings of the conference held at international livestock Centre for Africa; 1987 August 31st-September 4th; Addis Ababa, Ethiopia. Ethiopia: International Livestock Centre for Africa; 1988. pp.232-252.

42. Nkana JV, Demeyer A, Verloo MG. Chemical effects of wood ash on plant growth in tropical acid soils. Bioresour Technol. 1998; 63: 251-260.

43. Landon JR. Booker tropical soil manual: A handbook for soil survey and agricultural land evaluation in the tropics and subtropics. New York: Longman Scientific and Technical; 1991.

44. Naseli OD. A comparative study of changes in soil quality under two cropping systems in Santa, North West Region, Cameroon. Buea: Department of Development studies PAID-WA; 2016. pp.17-62.

45. Carrow RN. Clarifying soil testing: III. SLAN sufficiency ranges and recommendations. Golf Course Manag. 2004; 72: 194-198.

46. Food and Agriculture Organization of the United Nations. Better forestry, less poverty. A practitioner's guide. Forestry paper 149. Rome: Food and Agriculture Organization of the United Nations; 2006.

47. Bohn HL, McNeal BL, O'Connor GA. Soil chemistry. 3rd ed. New York: John Wiley and Sons, Inc.; 2001. pp.307.

48. Alemayehu T. Soil and irrigation management in the state farms. Proceedings of the first natural resource conservation conference. Natural Resource Degradation, a Challenge to Ethiopia; 1989 February 7th-8th; Addis Ababa, Ethiopia. Ethiopia: Institute of Agricultural research; 1990. pp.47-52.

49. Mesfin A. The challenges and future prospects of soil chemistry in Ethiopia. Proceedings of the 3rd Conference of the Ethiopian Society of Soil Science; 1996 February 28th-29th; Addis Ababa, Ethiopia. Ethiopia: Ethiopian Science and Technology Commission. pp.78-96.

50. Saikh H, Varadachari C, Ghosh K. Changes in carbon, nitrogen and phosphorus levels due to deforestation and cultivation: A case study in Simlipal National Park, India. Plant Soil. 1998; 198: 137-145.

51. Negassa W. Assessment of important physicochemical properties of Dystric Udalf (Dystric Nitosols) under different management systems in Bako area, western Ethiopia. Haramaya: Alemaya University; 2001. pp.93.

52. Beernaert F, Bitondo D. A simple and Practical Method to Evaluate Analytical Data of Soil Profiles. Belgia Cooperation Dschang, Cameroon: CUDs, Soil Science Department; 1992. 
53. Cass A. Measuring and managing chemical impediments to growth. Paraparaumu: Ryan Publications; 1998. pp.13-16.

54. Hazelton P, Murphy B. Interpreting soil test results: What do all the numbers mean? 2nd ed. Victoria: CSIRO publishing; 2007.

55. Fokeng MR. Land degradation modelling and implications in Southern Bui Plateau, Cameroon. Bamenda: The University of Bamenda; 2021. pp.459.

56. Asongwe GA, Yerima BP, Tening AS. Spatial variability of selected physico-chemical properties of soils under vegetable cultivation in urban and peri-urban wetland gardens of Bamenda municipality, Cameroon. Afr J Agric Res Dev. 2016; 11: 74-86.

57. Dabin B. Phosphorus deficiency in of tropical soils as a constraint on agricultural output. In: Soilrelated constraints to food production in the tropics. Los Banos: IRRI and Cornell University; 1988. pp.218-232.

58. Koala S, Sims JR, El-Attar H, El-Halfawi M. Phosphorus deficiency in the semi-arid tropics and implications for grain legume production. In: World crops: Cool season food legumes. Dordrecht: Springer; 1988. pp.205-216.

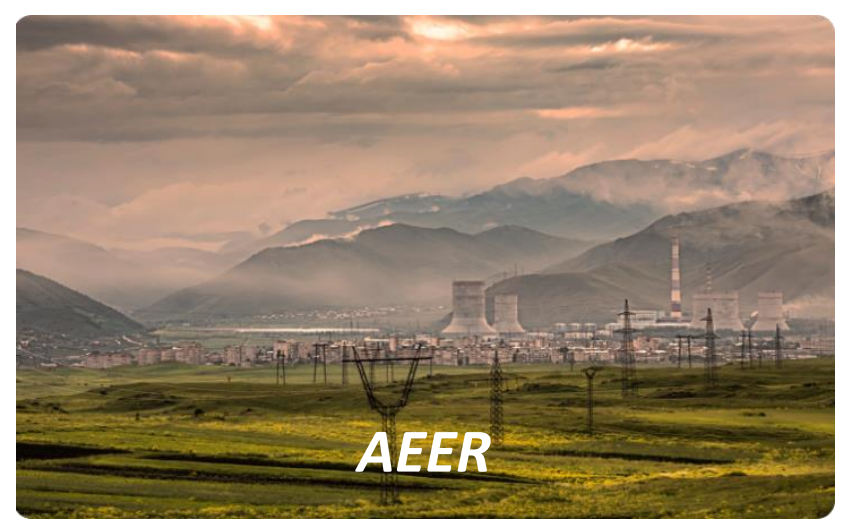

Enjoy $A E E R$ by:

1. Submitting a manuscript

2. Joining in volunteer reviewer bank

3. Joining Editorial Board

4. Guest editing a special issue

For more details, please visit:

http://www.lidsen.com/journals/aeer 